\title{
FAKTOR-FAKTOR YANG MEMPENGARUHI TURNOVER INTENTION KARYAWAN PADA PT. MANDIRI TUNAS FINANCE BENGKULU
}

\author{
Andriyani Prawitasari \\ Dosen Program Studi Manajemen Fakultas Ekonomi Universitas Dehasen Bengkulu
}

\begin{abstract}
ABSTRAK
Andriyani Prawitasari; Faktor-faktor yang mempengaruhi turnover intention karyawan pada PT. Mandiri Tunas Finance Bengkulu. Penelitian ini Penelitian ini bertujuan untuk mendeskripsikan faktor-faktor apa saja yang mempengaruhi turnover intention karyawan pada PT. Mandiri Tunas Finance Cabang Bengkulu. Metode pengambilan sample yang digunakan dalam penelitian ini adalah metode purposive convenience sampling. Purposive sampling adalah pemilihan sample berdasarkan pertimbangan tertentu, yakni diambil berdasarkan tujuan penelitian. Dalam penelitian ini yang menjadi sampel penelitian adalah beberapa orang pimpinan dan karyawan PT. Mandiri Tunas Finance Cabang Bengkulu. Penentuan responden dilakukan atas dasar pertimbangan, yaitu untuk pimpinan telah bekerja di PT. Mandiri Tunas Finance Cabang Bengkulu sejak dibukanya cabang Bengkulu. Khusus untuk karyawan, yang dijadikan sampel adalah karyawan yang masih tergolong baru bergabung diperusahaan dan berstatus kontrak. Hasil penelitian menunjukkan faktor-faktor yang mempengaruhi turnover intention yang diantaranya Usia, lama bekerja, tingkat pendidikan, keikatan terhadap organisasi, kepuasan kerja dan budaya perusahaan terlihat pada karyawan PT. Mandiri Tunas Finance Bengkulu
\end{abstract}

\section{ABSTRACT}

Andriyani Prawitasari; Some factors that influenced the turnover intention of employees in PT. Mandiri Tunas Finance Bengkulu. This research was mainly intended to figure out and described some factors that influenced the turnover intention of employees in PT. Mandiri Tunas Finance Bengkulu. Sample of methodthat used in research was purposive convenience sampling. Purposive sampling is the choices of sample based on deliberation, that took based on the goal of research. In this research, that has been of sampling were some of leaders and employees of PT. Mandiri Tunas Finance Bengkulu. Respondence based on deliberation, that for leaders has been worked in PT. Mandiri Tunas Finance Bengkulu since this opened in Bengkulu. Especially for employees, the new employees that joined with this corporation. The result of this research showed that some factors that influenced turnover intention were age, worked period, level of education, loyalty of organization, worked satisfication, and culture that showed in employees of PT. Mandiri Tunas Finance Bengkulu.

\section{Key Word: Turnover Intention}

\section{PENDAHULUAN}

Sumber Daya Manusia (SDM) merupakan aset paling penting dalam sebuah perusahaan, tanpa manusia maka sumber daya perusahaan tidak akan dapat menghasilkan laba atau menambah nilainya sendiri. Terlebih lagi bagi sebuah perusahaan yang menawarkan jasa, Dimana sumber daya manusia memegang peran penting sebagai ujung tombak perusahaan. Oleh sebab itu, perusahaan harus memprioritaskan untuk menemukan, mempekerjakan, memotivasi, melatih, dan mengembangkan karyawan yang dikehendaki perusahaan, serta mempertahankan karyawan yang berkualitas.

Sikap dan perilaku karyawan menentukakan kualitas dan kelangsungan hidup dari perusahaan itu. Hal ini disebabkan tanggung jawab untuk memberikan keuntungan yang kompetitif dan berkesinambungan untuk perusahaan sebagian besar berada di tangan para karyawan tersebut.

Salah satu upaya untuk mencapai target atau tujuan yang diinginkan perusahaanya itu dengan meminimalisasi tingkat perputaran karyawan (employee's turnover) dengan memperhatikan segala faktor yang menyebabkan keinginan karyawan untuk berpindah (turnover intention). Keinginan karyawan untuk berpindah disikapi dengan sebuah keadaan dimana karyawan mulai mendapati kondisi kerjanya sudah tidak sesuai lagi dengan apa yang diharapkan (Witasari, 2009).

Intensi turnover diartikan sebagai keinginan atau niat tenaga kerja keluar dari perusahaan. Turnover mengarah pada kenyataaan akhir yang dihadapi perusahaan berupa jumlah karyawan yang meninggalkan perusahaan pada periode tertentu, sedangkan keinginan karyawan untuk berpindah mengacu pada hasil evaluasi individu mengenai lanjutan hubungandengan perusahaan yang belum diwujudkan dalam tindakan pasti meninggalkan perusahaan. Turnover dapat berupa pengunduran diri, perpindahan keluar unit perusahaan, pemberhentian atau kematian anggota perusahaan (Witasari, 2009). 
Turnover mengakibatkan beberapa kerugian bagi perusahaan, seperti biaya yang harus ditanggung dan waktu yang dihabiskan untuk melakukan rekruitme, selection dan training agar mendapatkan karyawan yang memiliki kualitas yang sama dengan yang keluar dari perusahaan (Triaryati,2002).

Seiring semakin meningkatnya permintaan jasa kredit kendaraan bermotor di Indonesia, maka PT. Mandiri Tunas Finance cabang Bengkulu harus mengoptimalkan sumber daya manusia yang dimilikinya. Dimana saat ini mengumpulkan karyawan yang cakap dan berkinerja baik semakin sulit dilakukan, terlebih lagi mempertahankan yang sudah ada. Mereka harus memprioritaskan untuk menemukan, mempekerjakan, memotivasi, melatih, mengembangkan karyawan yang dikehendaki, hingga mempertahankan karyawan berkualitas. Disinilah dituntut adanya peranan penting manajemen sumber daya manusia (MSDM) dalam sebuah perusahaan.

Pihak perusahaan perlu memotivasi para pegawai untuk mencapai tujuan secara efektif, dengan senantiasa melakukan investasi untuk melakukan penerimaan, penyeleksian, dan mempertahankan pegawai potensial agar tidak berdampak pada turnover (perpindahan kerja) pegawai. Turnover intention (keinginan berpindah) adalah salah satu penyebab timbulnya turnover dan dapat mengarah langsung kepada turnover nyata, orang keluar dari pekerjaannya, meskipun belum mempunyai alternatif pekerjaan lain dengan alasan reward, keadilan (equity), dan rasa aman dari konflik-konflik yang terjadi didalam organisasi (Yuliani, 2005).

\section{LANDASAN TEORI}

\section{Manajemen Sumber Daya Manusia}

Menurut Handoko (2010:03) manajemen sumber daya manusia adalah penarikan, seleksi, pengembangan, pemeliharaan dan penggunaan sumber daya manusia untuk mencapai baik tujuan-tujuan individu maupun organisasi. Sedangkan menurut Marihot Tua (dalam Sunyoto, 2013:1) Manajemen Sumber Daya Manusia adalah aktivitas yang dilakukan merangsang, mengembangkan, memotivasi, dan memelihara kinerja yang tinggi dalam organisasi. Dimana sumber daya manusia dengan keseluruhan penentuan dan pelaksanaan berbagai aktivitas, policy, dan program yang bertujuan untuk mendapatkan tenaga kerja, pengembangan dan pemeliharaan dalam usaha meningkatkan dukungannya terhadap peningkatan efektivitas organisasi dengan cara yang secara etis dan sosial dapat dipertanggung jawabkan.

\section{Turnover}

Supriyanto (2003) yang dimaksud turnover yaitu proporsi jumlah anggota organisasi yang secara sukarela (voluntary) dan tidak (non vuluntary) meninggalkan organisasi dalamkurun waktu tertentu. Umumnya dinyatakan dalam satu tahun, turnover tidak boleh lebih dari 10\% pertahun. Cascio (1987) mendefinisikan turnover sebagai berhentinya hubungan kerja secara permanen antara perusahaan dengan karyawannya.Mobley (1986) seorang pakar dalam masalah pergantian karyawan memberi batasan turnover sebagai berhentinya individu dari anggota suatu organisasi dengan disertai pemberian imbalan keuangan oleh organisasi yang bersangkutan. Dari beberapa definisi mengenari turnover dapat disimpulkan bahwa turnover adalah berhentinya karyawan dari suatu perusahaan yang disertai imbalan oleh perusahaan yang bersangkutan.

\section{Turnover Intention Karyawan}

Pasewark dan Strawser (1996) menjelaskan bahwa turnover intention mengacu pada niat seseorang untuk mencari alternatif pekerjaan lain dan belum terwujud dalam bentuk perilaku nyata.

Mobley (1986) mengemukakan beberapa hal yang perlu dipahami untuk menemukan definsi umum turnover, antara lain:

1. Turnover berfokus pada karyawan, dalam arti mereka yang menerima upah dari organisasi suatu kondisi yang menunjukkan keanggotaan dari organisasi sebagai suatu kondisi yang menunjukkan keanggotaan karyawan dalam organisasi.

2. Turnover berfokus pada penghentian atau pemisahan diri karyawan dari organisasi.

3. Definisi umum turnover dapat dipakai untuk berbagai tipe organisasi dan pada berbagai macam tipe hubungan karyawan -organisasi.

Turnover intentions diindikasikan sebagai sikap individu yang mengacu pada hasil evaluasi mengenai kelangsungan hubungannya dengan organisasi dimana dirinya bekerja dan belum terwujud dalam bentuk tindakan pasti (Suwandi dan Indrantoro, 1999). Menurut Lekatompessy(2003) Turnover lebih mengarah pada kenyataan akhir yang dihadapi organisasi berupa jumlah karyawan yang meninggalkan organisasi. Mobley (1986) menyatakan keinginan (intensi) untuk keluar dari organisasi merupakan predictor dominan yang bersifat positif terhadap terjadinya turnover. Keinginan berpindah mengacu pada hasil evalasi 
individu mengenai kelanjutan hubungannya dengan organisasi dan belum ditunjukan tindakan pasti meninggalkan organisasi.

Tinggi rendahnya turnover karyawan pada suatu organisasi mengakibatkan tinggi rendahnya biaya perekrutan seleksi, dan pelatihan yang harus ditanggung organisasi. Hal ini dapat mengganggu efisiensi operasional organisasi, apalagi karyawan yang pindah tersebut memiliki pengetahuan, keterampilan, dan pengalaman yang baik. Namun dari segala efek negatif yang ada, turnover juga dapat memberikan dampak positif yaitu akan timbul kesempatan untuk individu yang memiliki keterampilan, motivasi dan loyalitas yang tinggi, Dalton danTodor (1981) dalam Irwandi (2002).

Mobley (1986) menyatakan bahwa banyak faktor yang menyebabkan karyawan berpindah dari tempat kerjanya namun faktor determinan keinginan untuk berpindah diantaranya adalah :

a. Kepuasan Kerja

Pada tingkat individual, kepuasan merupakan variable psikologis yang paling sering diteliti dalam suatu model intention turnover. Aspek kepuasan yang ditemukan berhubungan dengan keinginan individu untuk meninggalkan organisasi meliputi kepuasan akan upah dan promosi, kepuasan atas supervise yang diterima, kepuasan dengan rekan kerja, dan kepuasan akan pekerjaan dan isi kerja.

b. Komitmen Organisasi dari Karyawan

Karena hubungan kepuasan kerja dan keinginan meninggalkan tempat kerja hanya menerangkan sebagian kecil varian, maka jelas model proses turnover intention karyawan harus menggunakan variable lain di luar kepuasan kerja sebagai satu-satunya variable penjelas. Perkembangan selanjutnya dalam turnover intention memasukan konstruk komitmen organisasional sebagai konsep yang turut menjelaskan proses tersebut sebagai bentuk perilaku, komitmen organisasional dapat dibedakan dari kepuasan kerja. Komitmen mengacu pada responemosional (affective) individu kepada keseluruhan organisasi, sedangkan kepuasan mengarah pada respon emosional atas aspek khusus dari pekerja.

\section{Faktor Yang Mempengaruhi Turnover}

Faktor yang mempengaruhi terjadinya turnover cukup komplek dan saling berkaitan satu sama lain.diantara faktor-faktor tersebut yang akan dibahas antara lain adalah usia,lama kerja,tingkat pendidikan,keikatan terhadap organisasi,kepuasan kerja dan budaya perusahaan.

a. Usia

Maier (1971) mengemukakan pekerja muda mempunyai tingkat turnover yang lebih tinggi daripada pekerja-pekerja yang lebih tua.penelitian-penelitian terdahulu menunjukkan adanya hubungan yang signifikan antara usia dan intensi turnover dengan arah hubungan negatif. Artinya semakin tinggi usia seseorang, semakin rendah intensi turnovernya (dalam Mobley,1986). Karyawan yang lebih muda lebih tinggi kemungkinan untuk keluar.

Hal ini mungkin disebabkan pekerja yang lebih tua enggan berpindah-pindah tempat kerja karena berbagai alasan seperti tanggung jawab keluarga, mobilitas yang menurun,tidak mau repot pindah kerja dan memulai pekerjaan di tempat kerja baru,atau karena energi yang sudah berkurang, dan lebih lagi karena senioritas yang belum tentu diperoleh di tempat kerja yang baru walaupun gaji dan fasilitasnya lebih besar.

Gilmer (1966) berpendapat bahwa tingkat turnover yang cenderung tinggi pada karyawan berusia muda disebabkan karena mereka masih memiliki keinginan untuk mencoba-coba pekerjaan atau organisasi kerja serta ingin mendapatkan keyakinan diri lebih besar melalui cara 'coba-coba' tersebut. Selain itu karyawan yang lebih muda mungkin mempunyai kesempatan yang lebih banyak untuk mendapat pekerjaan baru dan memiliki tanggung jawab terhadap keluarga lebih kecil, sehingga dengan demikian lebih mempermudah mobilitas pekerjaan. Mungkin juga mereka mempunyai harapanharapan yang kurang tepat mengenai pekerjaan yang tidak terpenuhi pada pekerjaan-pekerjaan mereka yang sebelumnya (porter dan steer;Wanous dan mobley,1986).

b. Lama kerja

U.S. Civil Service Commission (1977) menyatakan bahwa pada setiap kelompok tertentu dari orangorang yang dipekerjakan, dua pertiga sampai tiga perempat bagian dari mereka yang keluar terjadi pada akhir tiga tahun pertama masa bakti, berdasarkan data ini lebih dari setengahnya sudah terjadi pada akhir tahun pertama (Mobley,1986). Hasil penelitian yang pernah dilakukan menunjukkan adanya korelasi negatif antara masa kerja dengan turnover, yang berarti semakin lama masa kerja semakin rendah kecenderungan turnovernya (prihastuti, 1992). Turnover lebih banyak terjadi pada karyawan dengan masa kerja lebih singkat (parson dkk, 1985). Interaksi dengan usia, kurangnya sosialisasi awal merupakan keadaan-keadaan yang memungkinkan terjadinya turnover tersebut.

c. Tingkat pendidikan 
Mowday, dkk (1982) berpendapat bahwa tingkat pendidikan berpengaruh pada dorongan untuk melakukan turnover. Dalam hal ini Maier (1971) membahas pengaruh intelegensi terhadap turnover. Dengan pendidikan yang tinggi dan jabatan yang sesuai maka berpengaruh terhadap retensi karyawan. Jika pendidikan tidak sesuai dengan jabatan yang diinginkan maka berpengaruh terhadap tingkat turnover yang tinggi.

d. Keikatan terhadap organisasi

Penelitian yang dilakukan oleh Hom dkk (1979); Michaels dan Spector (1982); Arnold dan Fieldman (1982); Steel dan Ovalle (1984) menemukan bahwa keikatan terhadap perusahaan mempunyai korelasi yang negatif dan signifikan terhadap intensi turnover. Berarti semakin tinggi keikatan seseorang terhadap perusahaannya akan semakin kecil ia mempunyai intensi untuk berpindah pekerjaan dan perusahaan, dan sebaliknya. Pekerja yang mempunyai rasa keikatan yang kuat terhadap perusahaan tempat ia bekerja berarti mempunyai dan membentuk perasaan memiliki (sense of belonging), rasa aman, efikasi, tujuan dan arti hidup, serta gambaran diri yang positif (Mowday dkk,1982) . Akibat secara langsung adalah menurunnya dorongan diri untuk berpindah pekerjaan dan perusahaan.

e. Kepuasan kerja

Penelitian yang dilakukan Mowday (1981); Michael dan Spector (1982); Arnold dan Fieldman (1982) menunjukkan bahwa tingkat turnover dipengaruhi oleh kepuasan kerja seseorang. Mereka menemukan bahwa semakin tidak puas seseorang terhadap pekerjaannya akan semakin kuat dorongannya untuk melakukan turnover.

Wexley dan Yukl (1977) mengatakan bahwa semakin banyak aspek-aspek atau nilai-nilai dalam perusahaan sesuai dengan dirinya maka semakin tinggi tingkat kepuasan yang dirasakan. Hal ini sejalan dengan discrepancy theory yang menyatakan bahwa kepuasan dapat tercapai bila tidak ada perbedaan antara apa yang seharusnya ada (harapan,kebutuhan,nilai-nilai) dengan apa yang menurut perasaan atau persepsinya telah diperoleh atau dicapai melalui pekerjaan.

f. Budaya perusahaan

Robbins (1998) menyatakan bahwa budaya perusahaan yang kuat memiliki pengaruh yang cukup besar terhadap perilaku karyawan dan secara langsung mengurangi turnover.Dalam budaya yang kuat, nilainilai utama sebuah organisasi atau perusahaan sangat dipegang teguh dan tertanam pada seluruh karyawannya. Semakin banyak karyawan yang menerima nilai-nilai tersebut dan semakin besar komitmen terhadapnya maka semakin kuat budaya perusahaan itu. Budaya yang kuat ini akan membentuk kohesivitas, kesetiaan, dan komitmen terhadap perusahaan pada para karyawannya, yang akan mengurangi keinginan karyawan untuk meninggalkan organisasi atau perusahaan.

\section{Kerangka Analisis}

Dari uraian diatas maka akan dapat digambarkan kerangka konseptual yang digunakan dalam penelitian ini. Berikut gambar kerangka konseptual dalam penelitian ini :

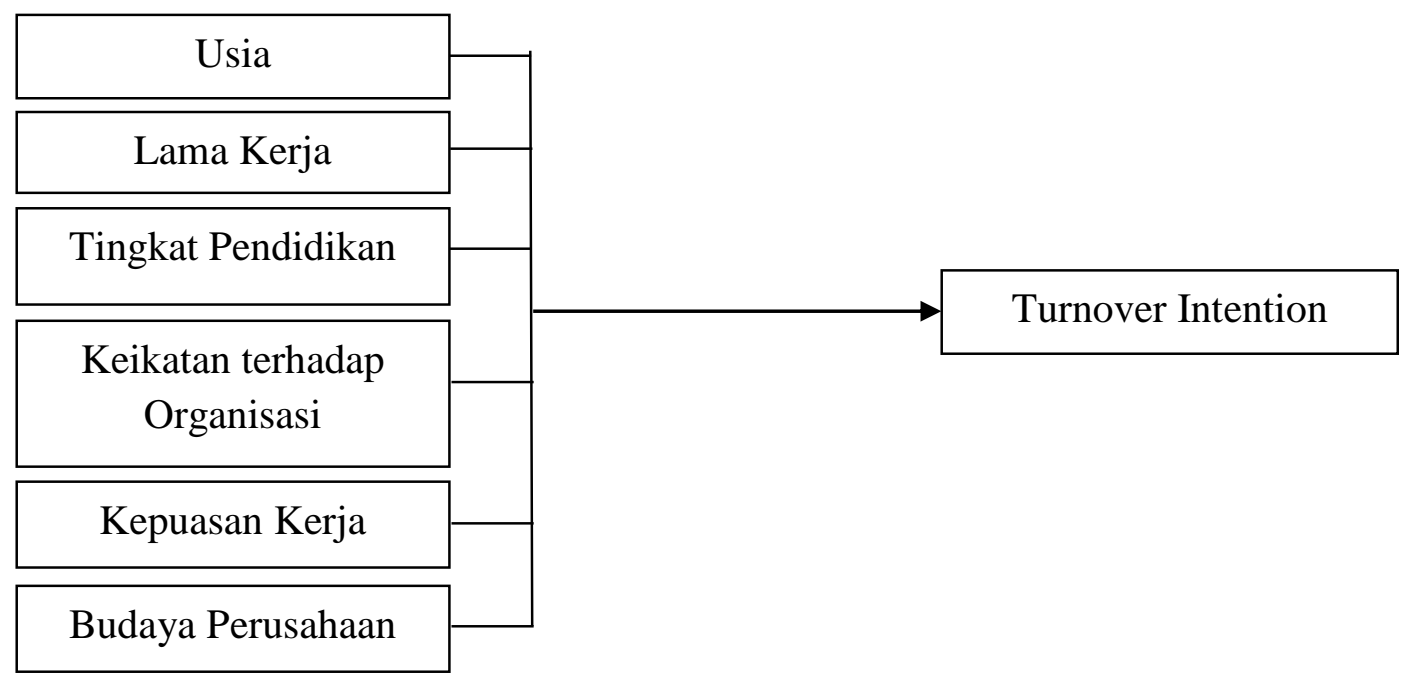

Gambar 1. Kerangka analisis

\section{METODE PENELITIAN \\ Jenis Penelitian}

Penelitian ini bertujuan untuk mendeskripsikan faktor-faktor apa saja yang mempengaruhi turnover intention karyawan pada PT. Mandiri Tunas Finance Cabang Bengkulu. Kajian mendalam perlu 
dilakukan agar substansi dari tujuan penelitian ini dapat diketahui yang meliputi apa saja yang mempengaruhi turnover intention karyawan pada PT. Mandiri Tunas Finance Cabang Bengkulu.

\section{Teknik Pengambilan Sampel}

Metode pengambilan sample yang digunakan dalam penelitian ini adalah metode purposive convenience sampling. Purposive sampling adalah pemilihan sample berdasarkan pertimbangan tertentu, yakni diambil berdasarkan tujuan penelitian, sedangkan convenience sampling adalah memilih anggota populasi yang paling mudah ditemui dan dimintai informasi (Hadi, 1987).

Dalam penelitian ini yang menjadi sampel penelitian adalah beberapa orang pimpinan dan karyawan PT. Mandiri Tunas Finance Cabang Bengkulu. Penentuan responden dilakukan atas dasar pertimbangan, yaitu untuk pimpinan telah bekerja di PT. Mandiri Tunas Finance Cabang Bengkulu sejak dibukanya cabang Bengkulu. Khusus untuk karyawan, yang dijadikan sampel adalah karyawan yang masih tergolong baru bergabung diperusahaan dan berstatus kontrak.

\section{Metode Pengumpulan Data}

Sugiono (2008:308) menyatakan teknik pengumpulan data merupakan langkah yang paling utama dalam penelitian, karena tujuan utama dari penelitian adalah mendapatkan data. Pengumpulan data dapat dilakukan dengan berbagai sumber dan cara. Bila dilihat dari sumber datanya, maka pengumpulan data dapat menggunakan sumber data primer dan skunder. Sumber data primer adalah data yang langsung diperoleh dari tangan pertama pemberi informasi. Sementara data sekunder adalah data yang diperoleh dari pihak tertentu dan data tersebut telah tersaji dalam bentuk data siap pakai.

Selanjutnya bila dilihat dari cara atau teknik pengumpulan data, maka teknik pengumpulan data dilakukan dengan cara :

- Wawancara. Tehnik wawancara dilakukan sebagai salah satu alat untuk mengumpulkan data primer didalam menghimpun informasi terkait dengan pelaksanaan penelitian. Wawancara adalah suatu bentuk komunikasi verbal untuk mendapatkan informasi secara langsung dengan mengungkapkan pertanyaanpertanyaan kepada responden. Teknik ini diperlukan untuk menggali dan memperoleh informasi mendalam tentang faktor-faktor yang mempengaruhi turnover intention karyawan di PT. Mandiri Tunas Finance Cabang Bengkulu.

\section{HASIL DAN PEMBAHASAN}

Dalam penelitian ini yang menjadi responden adalah beberapa orang pimpinan dan karyawan yang ada di PT. Mandiri Tunas Finance Cabang Bengkulu. Berdasarkan Tabel 4.2 terlihat bahwa yang menjadi responden adalah 6 orang berasal dari unsur pimpinan dan 16 orang dari unsur karyawan. Berdasarkan hasil pengumpulan data diperoleh bahwa dari kedua kelompok responden ini semuanya pimpinan telah memiliki masa kerja lebih dari lima tahun dan karyawan memiliki masa kerja dibawah dua tahun. Dengan demikian, diharapkan mereka dapat memberikan informasi yang cukup baik tentang faktor yang mempengaruhi turnover intention karyawan di PT. Mandiri Tunas Finance Cabang Bengkulu.

Tabel 1 Jabatan responden

\begin{tabular}{|l|l|c|}
\hline No. Jabatan & \multicolumn{1}{|c|}{ Jumlah responden } \\
\hline 1. & Branch Manager & 1 orang \\
\hline 2. & Operation Head & 1 orang \\
\hline 3. & Sales Head & 1 orang \\
\hline 4. & Credit Head & 1 orang \\
\hline 5. & Remedial Head & 1 orang \\
\hline 6. & Collection Head & 1 orang \\
\hline 7. & Sales Officer & 6 orang \\
\hline 8. & Collector & 6 orang \\
\hline 9. & Credit Admin & 2 orang \\
\hline 10. & Staff operation & 2 orang \\
\hline & \multicolumn{2}{|c|}{ Jumlah } \\
\hline
\end{tabular}

Sumber : PT. Mandiri Tunas Finance Cabang Bengkulu

Berikut ini akan diuraikan berbagai hal berkenaaan dengan hasil penelitian yaitu berupa hasil wawancara, rangkuman hasil wawancara dan pembahasan. Dari uraian ini akan melihat faktor yang mempengaruhi turnover intention karyawan di PT. Mandiri Tunas Finance Bengkulu. 


\section{Hasil wawancara \\ Usia}

Usia karyawan PT. Mandiri Tunas Finance Bengkulu telah ditetapkan perusahaan. Yaitu minimal usia 22 tahun. Baik untuk lulusan sarjana, maupun untuk lulusan SMA. Untuk batas maksimal umur perekrutan karyawan dengan usia 35 tahun. Karena rata-rata berusia muda, maka kemungkinan terjadinya turnover intention akan lumayan tinggi. Hal ini juga dibenarkan oleh Operation Head PT. Mandiri Tunas Finance Bengkulu. Yang dapat dilihat dari petikan wawancara berikut :

"Mungkin saja, karena usia muda masih ingin mencari-cari kerja yang menurut mereka nyaman dan sesuai dengan hati mereka. Dan juga mungkin beban target yang mereka terima melebihi kemampuan mereka yang berusia muda dan baru mulai masuk dunia kerja".

Turnover intention dapat terjadi karena ketidaksetabilan pegawai usia muda dalam menerima pekerjaan. Jika pekerjaan mereka anggap kurang menyenangkan, mereka dengan cepat bisa mengajukan pengunduran diri karena menganggap mereka masih muda, dan dapat mencari pekerjaan lain yang sesuai dengan mereka. Jika mereka tidak sanggup dengan beban target yang mereka terima, mereka juga akan berfikir untuk mengundurkan diri karena merasa usia mereka masih muda dan masih punya kesempatan untuk mencari kerja ditempat lain, Hal ini juga telihat dari salah satu karyawan PT. Mandiri Tunas Finance Bengkulu yang bekerja sebagai kolektor, ia menyatakan :

"karena saya masih muda, saya punya kesempatan untuk mendapatkan pekejaan ditempat lain.

Peluang saya lebih besar karena saya bekerja diusia lebih muda meskipun saya tamatan SMA".

Berdasarkan kutipan wawancara tersebut dari salah satu karyawan yang berusia muda, mereka optimis akan mendapatkan pekerjaan baru apabila mereka berhenti dari perusahaan tempat mereka bekerja.

\section{Lama Bekerja}

Lama bekerja karyawan PT. PT. Mandiri Tunas Finance Bengkulu bervariasi. Paling lama sudah sejak kantor cabang di Bengkulu buka pada 11 Agustus 2010. Kontrak kerja di perusahaan ini selama 2 tahun, dan akan diperpanjang lagi apabila kinerjanya baik untuk karyawan didivisi marketing dan collection. Dan untuk karyawan didivisi operation dan kredit, setelah 2 tahun akan langsung diangkat menjadi karyawan tetap tanpa harus diadakan tes lagi. Usia lama bekerja karyawan yang paling singkat kurang dari 1 tahun. Dikarenakan mengisi posisi lowongan yang kosong setelah ditinggal karyawan sebelumnya. Hal ini seperti disampaikan oleh salah satu staf marketing yang diwawancarai penulis :

"Saya baru bekerja 1 tahun. Saya direkrut karena ada posisi markering yang kosong, ada karyawan dibagian tempat saya bekerja mengundurkan diri".

Dari petikan wawancara diatas, bahwa lama bekerja pada PT. PT. Mandiri Tunas Finance Bengkulu yang baru membuka cabang di Bengkulu tidak semua dari saat kantor cabang dibuka. Tetapi ada yang baru direkrut setelah karyawan sebelumnya mengundurkan diri. Lama bekerja juga mempengaruhi turnover intention, semakin lama bekerja maka hubungan emotional terhadap perusahaan dan rekan kerja akan semakin kuat.

Untuk lama bekerja para pimpinan di PT. Mandiri Tunas Finance Bengkulu sudah sejak kantor cabang dibuka, tetapi tidak semua direkrut langsung menempati posisi supervisor, ada yang sebelumnya direkrut sebagai staf biasa lalu mendapat promosi naik jabatan. Sedangkan untuk Kepala Cabang di PT. Mandiri Tunas Finance Bengkulu paling lama menduduki jabatan hanya 2 tahun, setelah itu akan di rolling kekota lain. Hal ini seperti disampaikan oleh sales manager :

"Sejak kator cabang Bengkulu ini dibuka, saya melamar dengan posisi Credit head dan diterima".

Lama bekerja untuk posisi pimpinan dalam hal ini para supervisor, tidak terlalu membuat turnover intention berpengaruh. Karena posisi supervisor ini merupakan posisi yang mereka inginkan, secara emotional mereka telah terikat dengan perusahaan. Hal ini juga disampaikan oleh sales manager PT. Mandiri Tunas Finance Bengkulu :

"Saya bergabung diperusahaan ini sejak kantor cabang Bengkulu dibuka. Tetapi saya pertama masuk dulu diposisi sales officer, dan setelah 2 tahun bekerja saya mendapat promosi menjadi Sales Head. Kantor ini sudah menjadi rumah kedua saya, dan saya mencintai pekerjaan saya".

Dengan arti lain, turnover intention yang disebabkan oleh skala lama bekerja tidak terlalu terlihat pada tingkat level manajer.

\section{Tingkat Pendidikan}

Karyawan PT. Mandiri Tunas Finance Bengkulu memiliki tingkat pendidikan yang beragam. Ratarata untuk staf pendidikan minimal D3, kecuali untuk kolektor ada yang berpendidikan minimal SMA. Tingkat pendidikan juga sedikit mempengaruhi turnover intention pada PT. Mandiri Tunas Finance Bengkulu. Hal ini dapat terlihat dari beberapa orang karyawan yang dulunya pernah bergabung 
mengundurkan diri dengan alasan ingin fokus kuliah. Karena meraka beranggapan setelah menjadi sarjana ada lowongan dengan posisi yang lebih baik yang akan dapat mereka peroleh. Dari petikan wawancara berikut dengan salah satu staf kolektor, yang menyatakan :

"ada keinginan untuk mencari pekerjaan lain apabila saya sudah sarjana. Karena saya merasa saya kurang cocok di bidang collection ini. Karena pendidikan minimal SMA untuk posisi kolektor, jadi saya mencoba sekaligus mencari pengalaman."

Turnover intention yang disebabkan tingkat pendidikan dapat terjadi. Hal ini dikarenakan apabila jenjang pendidikan seseorang naik, maka ada keinginan untuk lebih dihargai, minimal dalam sikap kerja dan kompensasi. Mereka yang lulusan sarjana akan merasa tidak adil apabila disetarakan dengan lulusan SMA. Adanya keinginan untuk mendapatkan posisi yang lebih baik sesuai dengan jenjang pendidikannya diperusahaan. Jika mereka tidak mendapatkannya, maka kemungkinan besar Turnover intention akan terjadi. Hal senada diungkapkan oleh salah satu kolektor yang lain :

"apabila saya sudah lulus kuliah dan meraih gelar sarjana, saya berharap akan ditempatkan diposisi yang lain. Tidak hanya dilapangan, tetapi bisa menjadi staf pendukung kolektor dikantor. Jika ijazah sarjana saya tidak berpengaruh, mungkin saja saya kan mencari pekerjaan lain yang lebih menghargai ijazah sarjana saya".

Hal ini juga dapat terlihat dari petikan wawacara berikut, dari salah satu staf kredit :

"saya baru bergabung di kantor ini selama 2 tahun, karena ada posisi kosong di staf kredit. Karena staf kredit sebelumnya mengundurkan diri. Menurut informasi salah satu alasannya mengundurkan diri karena dia merasa pendidikannya kurang dihargai. Dia lulusan s2, tetapi dikantor kita punya 3 supervisor yang hanya lulusan SMA"

\section{Keikatan terhadap organisasi}

Setiap karyawan PT. Mandiri Tunas Finance Bengkulu memiliki keikatan terhadap perusahaan. Tetapi rasa keterikatan berbeda-beda, semakin lama waktu bergabung dengan perusahaan. Rasa keterikatan bisa semakin erat. Hal ini terlihat dari hasil wawancara dengan salah satu staf operation :

"rasa keterikatan itu pasti ada, karena disini tempat saya mencari nafkah. Jadi saya mencintai perusahaan dan pekerjaan saya agar saya bisa merasa nyaman berada dikantor. Karena saya baru bergabung 1 tahun diperusahaan ini, mungkin rasa keterikatan saya tidak sebesar temanteman yang lain"

Lain halnya dengan para pimpinan di PT. Mandiri Tunas Finance Bengkulu, semua pimpinan merasakan keterikatan terhadap perusahaan. Tidak perduli berapa lama mereka bergabung dengan perusahaan, keterikatan itu ada lebih dikarenakan juga karena adanya rasa tanggung jawab yang besar untuk memajukan perusahaan. Hal ini dapat dilihat dari hasil petikan wawancara dengan Remedial Head PT. Mandiri Tunas Finance Bengkulu :

"pasti ada rasa keterikatan, kalau tidak ada maka kemungkinan kita bekerja asal-asalan, tidak ikhlas dan hasil kerjaan kita juga tidak akan berjalan dengan baik. Saya juga bergabung dengan kantor ini sudah sejak kantor ini berdiri di Bengkulu, jadi saya sudah merasa kantor ini rumah kedua saya".

\section{Kepuasan Kerja}

Kepuasan kerja karyawan PT. Mandiri Tunas Finance Bengkulu terhadap pekerjaan yang dibebankan oleh mereka berbeda-beda dan tergantung posisi yang mereka emban. Terutama untuk para karyawan dilapangan yang mempunyai target, sebagian karyawan merasa target yang dibebankan kepada mereka terlalu besar. Sehingga dapat menimbulkan rasa ketidakpuasan terhadap pekerjaan. Hal ini dapat terlihat dari salah satu staf kolektor yang menyampaikan melalui wawancara :

"saya berharap target yang dibebankan kepada saya terutama tidak sebesar ini, sehingga sulit untuk saya mencapai target yang dibebankan kepada saya. Apabila saya tidak bisa mencapat target, saya akan mendapat teguran keras dan tidak bisa mendapatkan insentif"

Kepuasan kerja salah satunya bisa disebabkan oleh posisi kerja yang tidak nyaman. Terkadang ada rasa keinginan untuk merasakan posisi orang lain. Bosan dan jenuh dengan pekerjaan yang dikerjakan selama ini. Dan berharap ada mutasi karyawan. Hal ini disampaikan oleh salah satu staf operation yang menduduki posisi sebagai kasir melalui hasil wawancara :

"saya sudah dua tahun menduduki posisi ini, ada keinginan untuk dimutasi kebagian lain. Karena saya cukup jenuh mengerjakan pekerjaan ini saja. Saya berharap kalau ada nya pertukaran posisi dengan staf bagian lain. "

Untuk tingkat manager kepuasaan kerja tidak nampak berpengaruh pada turnover intention. Kepuasaan kerja terlihat lebih untuk memenuhi target dan tantangan dari perusahaan. Hal ini disampaikan oleh Collection Head PT. Mandiri Tunas Finance Bengkulu seperti kutipan berikut : 
"untuk saya pribadi kepuasan kerja itu tercipta apabila unit bagian pekerjaan saya berjalan lancar, tidak ada kendala, akan membuat saya merasa puas dan bersemangat. Tanggung jawab kami sebagai supervisor dapat terpenuhi dengan baik maka akan tercapainya kepuasan kerja".

Apabila pekerjaan yang dibebankan kepada supervisor setiap divisi bisa mereka lakukan dengan baik. Maka kepuasan kerja akan tercipta. Kepuasaan kerja ini berdampak baik terhadap supervisor. Turnover intention dengan skala kepuasaan kerja tidak terlihat pada para manager di PT. Mandiri Tunas Finance Bengkulu.

\section{Budaya Perusahaan}

Pada PT. Mandiri Tunas Finance Bengkulu, budaya perusahaan cukup terlihat baik dimata karyawan maupun pimpinan. Hanya saja sebagian besar karyawan sulit menyesaikan diri dengan budaya organisasi, terutama dalam hal mencapai target yang dibebankan. Karena pada perusahaan ini memberikan peraturan apabila dalam 3 (tiga) bulan berturut-turut tidak mencapai target, maka akan mendapatkan SP (Surat peringatan) 1. Apabila 3 (bulan) kedapan tidak mencapai target lagi, maka bisa langsung diberhentikan tanpa harus menunggu SP (surat peringatan) 2. Hal ini dapat dilihat dari petikan wawancara dengan salah satu kolektor berikut :

" saya karyawan baru yang direkrut 2 bulan yang lalu, karena ada kebutuhan kolektor baru. Karyawan sebelumnya diberhentikan karena dalam 6 bulan tidak mencapai target. Dan pada wawancara perekrutan saya, saya diberitahukan apabila saya tidak mencapai target dalam 3 bulan, saya juga bisa diberhentikan tanpa surat peringatan. Karena keputusan mutlak ada pada divisi masing-masing, bisa tidak mengikuti peraturan atau kebijakan dari kantor pusat."

Lingkungan perusahaan cukup nyaman, tetapi sebagian besar karyawan merasa adanya batasan yang sulit dihadapi dengan beberapa supervisor. Hal ini terlihat dari petikan wawancara terhadap salah satu staf collection :

"Peraturan dan jam kerja perusahaan tidak ada yang berat, dan lingkungan pekerjaan cukup nyaman, tetapi terkadang yang bikin tidak nyaman adalah hubungan antar karyawan dan atasan. Karyawan merasa takut dengan atasan dikarenakan cara atasan menghadapi para karyawan yang kurang bersahabat".

Untuk skala budaya organisasi yang menyebabkan turnover intention pada PT. Mandiri Tunas Finance cukup terlihat. Karena sebagian besar karyawan merasa terbebani dengan budaya perusahaan yang dapat mengambil keputusan tanpa pemberitahuan dan tidak mengikuti kebijakan yang diberikan oleh kantor pusat. Dan juga merasa adanya batasan dengan atasan langsung atau supervisor.

\section{Rangkuman Hasil Wawancara}

Berdasarkan petikan wawancara yang telah dikemukakan di atas maka rangakaian wawancara lain yang dilakukan dalam penelitian ini guna menggali informasi faktor-faktor yang mempengaruhi turnover intention pada PT. Mandiri Tunas Finance Bengkulu dapat dirangkum sebagai berikut:

Usia

Dari hasil wawancara terhadap 22 orang karyawan yang mewakili keseluruhan staf, menyatakan rata-rata karyawan direkrut dengan usia minimal 22 tahun.

\section{Lama Bekerja}

Dari hasil wawancara dengan para supervisor dan juga staf yang menjadi responden, menghasilkan jawaban yang berbeda-beda. Untuk level supervisor bekerja di perusahaan sudah cukup lama. Rata-rata diatas 5 tahun. Sejak kantor cabang dibuka. Untuk level staf, beberapa staf bekerja sejak kantor cabang PT. Mandiri Tunas Finance Bengkulu ini dibuka yaitu sejak 11 Agustus 2010. Dan sudah menjadi karyawan tetap. Beberapa staf sudah bergabung selama 2 sampai 3 tahun, dan juga sudah menjadi karyawan tetap. Sebagian staf lagi yang diwawancara menyatakan baru bergabung antara 6 bulan sampai 1 (satu) setengah tahun dengan perusahaan dikarenakan menggantikan posisi yang lowong akibat ditinggal karyawan sebelumnya. Dan belum mengalami perpanjangan kontrak.

\section{Tingkat Pendidikan}

Dari hasil wawancara untuk para supervisor, tidak semua manager lulusan sarjana strata 1 (S1). Ada 3 orangan supervisor yang hanya lulusan SMA, dan sedang menempuh pendidikan untuk meraih gelar sarjana. Sedangkan untuk para staf, dari hasil wawancara sebagian besar menyatakan lulusan D3 dan S1, dan sebagian kecil lulusan SMA. 


\section{Keikatan terhadap organisasi}

Dari hasil wawancara dengan responden, semua supervisor menyatakan mempunyai keikatan terhadap organisasi atau perusahaan. Sehingga tidak ada keinginan mereka untuk pindah perusahaan. Sedangkan untuk responden dengan level staf, beberapa menyatakan ada rasa keterikatan terhadap perusahaan karena sudah lama bekerja. Sehingga keinginan untuk berpindah itu tidak. Sebagian besar menyatakan keinginan berpindah ada karena keterikatan terhadap perusahaan belum terlalu besar.

\section{Kepuasan Kerja}

Dari hasil wawancara, semua supervisor menyatakan akan merasakan kepuasan kerja apabila target dan pekerjaan mereka dapat dilaksanakan dengan baik dan maksimal. Sehingga tidak ada keinginan mereka untuk pindah perusahaan. Sedangkan untuk responden dengan level staf, beberapa orang karyawan pada divisi collection dan marketing merasakan ketidakpuasan dalam bekerja karena target yang dibebankan terlalu besar sehingga target tidak tercapai. Beberapa karyawan pada divisi operation dan credit mempunyai keinginan merasakan posisi lain selain posisi mereka saat ini. Mereka berharap adanya mutasi kerja sehingga tidak merasa jenuh dengan pekerjaan mereka. Apabila keingian mereka dapat terpenuhi, makan kepuasaan kerja akan timbul dan keinginan berpindah bisa berkurang.

\section{Budaya Perusahaan}

Dari hasil wawancara dengan sebagian besar karyawan yang menyatakan budaya dan peraturan perusahaan sedikit memberatkan karyawan. Hubungan dengan atasan langsung atau supervisor ada batasan yang membuat karyawan merasa kurang nyaman

\section{Pembahasan}

Berdasarkan hasil wawancara dengan 5 (lima) orang supervisor, 1 (satu) orang kepala cabang dan 16 (enam belas) orang staf yang mewakili keseluruhan karyawan dapat dinyatakan bahwa turnover intention yang terjadi pada PT. Mandiri Tunas Finance Bengkulu cukup tinggi dikarenakan banyak karyawan lapangan yang direkrut usia muda. Sehingga memiliki keinginan besar untuk bisa mendapatkan pekerjaan yang lebih baik atau sesuai dengan keinginan ditempat lain. Dari hasil pengumpulan data juga dapat diketahui bahwa tingkat pendidikan juga dapat menjadi faktor turnover intention pada PT. Mandiri Tunas Finance Bengkulu, terutama terhadap karyawan. Lama bekerja juga mempengaruhi turnover intention pada PT. Mandiri Tunas Finance Bengkulu, terutama untuk para karyawan lapangan yang masih berstatus kontrak.

Untuk semua supervisor dan kepala cabang pada PT. Mandiri Tunas Finance Bengkulu, merasakan keterikatan terhadap perusahaan, 16 orang dari 26 orang karyawan lapangan yang terdiri dari kolektor dan sales officer belum merasakan keterikatan terhadap perusahaan. Karena mereka masih terbilang baru bergabung pada PT. Mandiri Tunas Finance Bengkulu, sedangkan untuk staf officer 5 dari 14 orang merasakan kurangnya keteriatan terhadap perusahaan. Karena merasa usia masih muda dan punya banyak kesempatan kerja di perusahaan lain.

Kepuasan kerja pada PT. Mandiri Tunas Finance Bengkulu, dengan seluruh supervisor dan kepala cabang merasa puas dengan kinerja terhadap perusahaan apabila target yang dibebankan perusahaan dapat tercapai. Dan untuk dikalangan staf sebagian besar staf marketing dan collection merasa berat dengan target yang dibebankan perusahaan, sehingga menimbulkan ketidakpuasan dalam bekerja. Beberapa staf officer pada PT. Mandiri Tunas Finance Bengkulu merasa kurang puas dengan posisi yang ditempat sekarang, mereka mempunyai keinginan untuk mutasi atau pindah bagian sehingga tidak merasa bosan dengan pekerjaan yang ada. Dari persentase tersebut, dapat dilihan kurangnya kepuasan kerja dapat menyebabkan turnover intention. Budaya organisasi pada PT. Mandiri Tunas Finance Bengkulu tidak menyebabkan terjadinya turnover intention. Dikarenakan semua staf dari mulai level supervisor, kepala cabang hingga seluruh staf merasakan budaya organisasi di PT. Mandiri Tunas Finance Bengkulu berjalan dengan baik.

\section{KESIMPULAN}

1. Usia menjadi salah satu faktor turnover intention pada PT. Mandiri Tunas Finance Bengkulu. Terutama untuk karyawan pada divisi marketing dan collection diperusahaan itu yang berusia muda. Sehingga rentan untuk berpindah ke perusahaan lain.

2. Lama bekerja juga menjadi salah satu faktor turnover intention pada PT. Mandiri Tunas Finance Bengkulu Semakin lama bekerja diperusahaan semakin ada rasa enggan meninggalkan perusahaan. Tetapi waktu singkat bergabung dalam perusahaan juga bisa mempengaruhi karyawan untuk enggan berpindah perusahaan karena merasa baru akan beradaptasi. 
3. Tingkat pendidikan berpengaruh terhadap turnover intention pada PT. Mandiri Tunas Finance Bengkulu. Adanya keinginan untuk mendapatkan posisi yang lebih baik dan pekerjaan yang lebih baik apabila pendidikan meningkat.

4. Keterikatan terhadap organisasi juga merupakan faktor turnover intention pada PT. Mandiri Tunas Finance Bengkulu. Apabila karyawan merasa sudah nyaman dengan perusahaan dan merasa ada keterikatan khusus, maka turnover intention tidak akan terjadi.

5. Kepuasaan kerja pada PT. Mandiri Tunas Finance Bengkulu juga mempengaruhi turnover intention. Semakin merasa puas dengan kinerja, akan menimbulkan semangat kerja, sehingga tidak terjadi turnover intention.

6. Budaya perusahaan yang kurang membuat nyaman para karyawan dapat membuat turnover intention pada PT. Mandiri Tunas Finance Bengkulu akan terjadi.

\section{Saran}

1. Untuk karyawan berusia muda dan masih belum kuliah, hendaknya dibina dengan baik, jika mereka pada akhirnya menempuh pendidikan kejenjang yang lebih tinggi, mereka tidak berfikir untuk meninggalkan perusahaan. Dan hendaknya diperusahaan diberikan apresiasi yang lebih kepada karyawan dengan jenjang pendidikan yg lebih tinggi, misalkan berupa gaji pokok yang lebih besar dari karyawan yang jenjang pendidikannya lebih rendah. Sehingga mereka merasa dihargai. Seperti layaknya pegawai negeri yang tingkat pendidikannya lebih tinggi, mendapat golongan yang lebih tinggi dan gaji yang lebih besar. Sehingga mereka yang hanya lulusan SMA termotivasi untuk meraih gelar sarjana, tanpa berfikir untuk meninggalkan perusahaan.

2. Untuk karyawan yang sudah menduduki satu posisi cukup lama, hendaknya dilakukan mutasi kebagian lain, sehingga tidak merasa jenuh dan bosan, juga mendapatkan pengalaman dan ilmu dibidang lain. Untuk target perusahaan yang memberatan karyawan, hendaknya dipertimbangkan berdasarkan pengalaman mereka dalam bekerja.

3. Hubungan antara karyawan dan atasan ditingkatkan, ciptakan suasana kantor yang bersahabat sehingga membuat karyawan merasa nyaman. Dan peraturan perusahaan dalam pemberhentian kerja juga dipertegas dari awal, sehingga tidak menimbulkan kekecewaan.

\section{DAFTAR PUSTAKA}

Ridlo, Ilhan Akhsanu. 2012.Turn Over Karyawan "KajianLiteratur", Surabaya: Public Health Movement

Abelson, M.A. 1986. Startegic Management of Turnover : a model for the health service Administrator, Health Care Manage Review, Vol.11(2),pp61-71

Flippo, E.B. 1997. Manajemen Personalia.Edisi Keenam Jilid 2, Alih Bahasa Moh. MAsud. Jakarta, Airlangga

Hasibuan, M.S.P. 1999. Manajemen Sumberdaya Manusia dasar dan Kunci Keberhasilan. Ed 2. Jakarta, Penerbit Toko Gunung Agung

Mobley,W. H. 1986. Pergantian Karyawan: Sebab, Akibat Dan Pengendaliannya. Terjemah.Jakarta: PT Pustaka Binaman Pressindo

Mowday, R.T., L.W. Porter and R.M Steers, 1982. Employee Orgabization Linkages: The Psychology of Commitment Absenteism and Turnover. New York: Academic Press

Robbins, S.P. 2006. Perilaku Organisasi, Jakarta: Indek Group Gramedia

Sunyoto, Drs. Danang. 2013. Manajemen Sumber Daya Manusia. Jakarta. CAPS.

Tb. Sjafri Mangkuprawiradan Aida Vitalaya Hubeis, 2007. Manajemen Mutu SDM, PT. Ghalia Indonesia, Jakarta. 